\title{
Hereditary angioedema as a disease of different clinical courses and difficult diagnosis, particularly in children - a case report and literature review
}

\author{
Aneta Krogulskaํ, Dorota Lewandowska ${ }^{1}$, Hanna Ludwig', Anna Dąbrowska², Agnieszka Kowalczyk ${ }^{1}$ \\ ${ }^{1}$ Department of Paediatrics, Allergology and Gastroenterology, Ludwik Rydygier Collegium Medicum in Bydgoszcz, Nicolaus Copernicus \\ University in Torun, Poland \\ 2Department of Paediatric Haematology and Oncology, Ludwik Rydygier Collegium Medicum in Bydgoszcz, Nicolaus Copernicus \\ University in Torun, Poland \\ Adv Dermatol Allergol 2021; XXXVIII (6): 1118-1121 \\ DOI: https://doi.org/10.5114/ada.2021.106249
}

Hereditary angioedema (HAE) is a rare genetic disease with potentially fatal consequences [1]. Its estimated occurrence ranges from $1: 10,000$ to $1: 50,000$ [2]. A few types of HAE have been differentiated. HAE types 1 and 2 are most common, with depleted $\mathrm{C} 1$ inhibitor esterase (C1-INH) in serum or its dysfunction caused by a mutated SERPING1 gene [3]. The illness is mainly inherited through autosomal dominance, with 20-25\% of cases caused by de novo mutation [4]. C1-INH, a member of the serpin group proteins, is a natural inhibitor of the initial phase of the complement cascade. Disrupting its concentration or function causes uncontrolled bradykinin production and accumulation, due to non-physiological activation of the complement system, the coagulation pathway, fibrinolysis and kallikrein cascade. When bound to its specific type 2 receptors, bradykinin induces a rapid increase in subcutaneous and submucosal blood vessel permeability, manifested as recurrent episodes of subcutaneous and submucosal tissue oedema.

This paper, basing on literature review from the 5 last years, presents 2 cases of HAE, with different clinical courses, where the condition was diagnosed at the age of 13 and 16 years. In both cases, the diagnosis was established many years after the first clinical symptoms, and in one, despite a positive family history.

A 16-year-old girl was admitted with oedema of the lips, hand and foot, which had recurred since 11 years of age: three times for oedema of the lips, and five times for oedema of the foot and hand. The asymmetrical oedemas were painless, developed over a few to $36 \mathrm{~h}$ and disappeared after one to four days; they lacked any obvious cause and were not accompanied by other symptoms. The girl's mother had also experienced oedemas of the hands and feet. Previously, the girl had been treated with antihistamines and general steroids by her GP and the Emergency Department. However, following initial improvement, further use of treatment proved ineffective. At the age of 16, upon admission to the hospital, her general condition was good. Oedema of the upper lip and the cheeks was identified during the first hospitalisation, and a severe oedema of the right foot and hand during the second (generally she was 2 times in hospital). Basic laboratory test results were within norms (Table 1 ). Two tests performed over subsequent months revealed insufficient C4 complement in serum and reduced C1-INH activity and concentration (Table 1 ). A diagnosis of HAE type 1 was confirmed.

A 13-year-old girl was admitted with recurring abdominal pains, vomiting and diarrhoea. The history revealed an appendectomy at nine years of age and ultrasound examination indicated a large amount of the fluid in the retroperitoneal space. Since then, she had been hospitalized many times with abdominal pains, both in the Department of Surgery and in Paediatrics (6 times). At 10 years of age, an endoscopic examination of the digestive tract was performed in response to abdominal pains, vomiting and the presence of blood and mucus in the stools; although no macroscopic abnormalities were visible, histopathological examination identified inflammatory infiltrations which may be inflammatory bowel disease (IBD). Magnetic resonance imaging (MRI) with enterography did not identify any changes typical of IBD; however, based on the overall clinical picture, mesalazine was prescribed and continued until the age of 13 years. Despite treatment, the symptoms returned. Further tests were performed to exclude other causes.

\footnotetext{
Address for correspondence: Aneta Krogulska MD, PhD, Prof. NCU, Department of Paediatrics, Allergology, and Gastroenterology, Collegium Medicum, Nicolaus Copernicus University, 9 Skłodowskiej-Curie St, 85-094 Bydgoszcz, Poland, phone: +48 525854850 , e-mail: anetkrog@poczta.onet.pl

Received: 24.07.2020, accepted: 3.12.2020.
} 
Table 1. Test results in case 1 and 2

\begin{tabular}{|c|c|c|c|c|c|}
\hline Tests & & Case 1 & Norm & Case 2 & Norm \\
\hline \multirow[t]{5}{*}{ Blood count } & WBC & $9.05 \mathrm{~K} / \mu \mathrm{l}$ & $4.5-13.0 \mathrm{~K} / \mu \mathrm{l}$ & $12.06 \mathrm{~K} / \mu \mathrm{l}$ & $4.5-13.5 \mathrm{~K} / \mu \mathrm{l}$ \\
\hline & RBC & $5.54 \mathrm{M} / \mu \mathrm{l}$ & $4.1-5.1 \mathrm{M} / \mu \mathrm{l}$ & $5.72 \mathrm{M} / \mu \mathrm{l}$ & $3.8-5.0 \mathrm{M} / \mu \mathrm{l}$ \\
\hline & HGB & $15.7 \mathrm{~g} / \mathrm{dl}$ & $12.0-16.0 \mathrm{~g} / \mathrm{dl}$ & $16.2 \mathrm{~g} / \mathrm{dl}$ & $12.0-15.0 \mathrm{~g} / \mathrm{dl}$ \\
\hline & $\mathrm{HCT}$ & $46.6 \%$ & $36-46 \%$ & $47.1 \%$ & $34.0-43.0 \%$ \\
\hline & PLT & $309 \mathrm{~K} / \mu \mathrm{l}$ & $140-440 \mathrm{~K} / \mu \mathrm{l}$ & $312 \mathrm{~K} / \mu \mathrm{l}$ & $175-345 \mathrm{~K} / \mu \mathrm{l}$ \\
\hline \multirow[t]{3}{*}{ Electrolytes } & Sodium & $141 \mathrm{mmol} / \mathrm{l}$ & $138-145 \mathrm{mmol} / \mathrm{l}$ & $139 \mathrm{mmol} / \mathrm{l}$ & $132-145 \mathrm{mmol} / \mathrm{l}$ \\
\hline & Potassium & $4.8 \mathrm{mmol} / \mathrm{l}$ & $3.4-4.7 \mathrm{mmol} / \mathrm{l}$ & $4.6 \mathrm{mmol} / \mathrm{l}$ & $4.1-5.3 \mathrm{mmol} / \mathrm{l}$ \\
\hline & Chlorine & $102 \mathrm{mmol} / \mathrm{l}$ & 98-106 mmol/l & $104 \mathrm{mmol} / \mathrm{l}$ & 96-111 mmol/l \\
\hline \multirow[t]{4}{*}{ Immunoglobulins } & $\lg A$ & $1.41 \mathrm{~g} / \mathrm{l}$ & $0.85-1.94 \mathrm{~g} / \mathrm{l}$ & $1.74 \mathrm{~g} / \mathrm{l}$ & $0.62-2.30 \mathrm{~g} / \mathrm{l}$ \\
\hline & $\mathrm{tlgE}$ & $46.7 \mathrm{IU} / \mathrm{ml}$ & $0.10-87 \mathrm{IU} / \mathrm{ml}$ & & \\
\hline & $\lg G$ & $13.06 \mathrm{~g} / \mathrm{l}$ & $7.06-14.40 \mathrm{~g} / \mathrm{l}$ & $10.0 \mathrm{~g} / \mathrm{l}$ & $7.08-14.40 \mathrm{~g} / \mathrm{l}$ \\
\hline & $\lg M$ & $0.90 \mathrm{~g} / \mathrm{l}$ & $0.44-1.13 \mathrm{~g} / \mathrm{l}$ & $1.20 \mathrm{~g} / \mathrm{l}$ & $0.50-2.13 \mathrm{~g} / \mathrm{l}$ \\
\hline \multicolumn{2}{|c|}{ SPT and slgE with food and inhalant allergens } & $<0.35 \mathrm{kU} / \mathrm{l}$ & & & \\
\hline \multicolumn{2}{|c|}{ Erythrocyte sedimentation rate } & - & & $4 \mathrm{~mm}$ & $1-15 \mathrm{~mm}$ \\
\hline \multicolumn{2}{|l|}{ C-reactive protein } & - & & $14.97 \mathrm{mg} / \mathrm{l}$ & $<5.00 \mathrm{mg} / \mathrm{l}$ \\
\hline \multicolumn{2}{|l|}{ Serum urea } & $24.1 \mathrm{mg} / \mathrm{dl}$ & $19-49 \mathrm{mg} / \mathrm{dl}$ & $24.1 \mathrm{mg} / \mathrm{dl}$ & $19-49 \mathrm{mg} / \mathrm{dl}$ \\
\hline \multicolumn{2}{|l|}{ Serum creatinine } & $0.61 \mathrm{mg} / \mathrm{dl}$ & $0.50-1.10 \mathrm{mg} / \mathrm{dl}$ & $0.54 \mathrm{mg} / \mathrm{dl}$ & $0.50-1.10 \mathrm{mg} / \mathrm{dl}$ \\
\hline \multicolumn{2}{|l|}{ Asparagine transaminase } & $21 \mathrm{U} / \mathrm{l}$ & $<25 \mathrm{U} / \mathrm{l}$ & $17 \mathrm{U} / \mathrm{l}$ & $<25 \mathrm{U} / \mathrm{l}$ \\
\hline \multicolumn{2}{|l|}{ Alanine transaminase } & $23 \mathrm{U} / \mathrm{l}$ & $<23 \mathrm{U} / \mathrm{l}$ & $22 \mathrm{U} / \mathrm{l}$ & $<23 \mathrm{U} / \mathrm{l}$ \\
\hline \multicolumn{2}{|l|}{ Alkaline phosphatase } & - & & $133 \mathrm{U} / \mathrm{l}$ & $<448 \mathrm{U} / \mathrm{l}$ \\
\hline \multicolumn{2}{|c|}{ Gamma-Glutamyl transpeptidase } & - & & $12 \mathrm{U} / \mathrm{l}$ & $<23 \mathrm{U} / \mathrm{l}$ \\
\hline \multicolumn{2}{|l|}{ Serum amylase } & - & & $36 \mathrm{U} / \mathrm{l}$ & $30-118 \mathrm{U} / \mathrm{l}$ \\
\hline \multicolumn{2}{|l|}{ Lactic dehydrogenase } & - & & $199 \mathrm{U} / \mathrm{l}$ & $<436 \mathrm{U} / \mathrm{l}$ \\
\hline \multicolumn{2}{|l|}{ Albumin } & $4.2 \mathrm{~g} / \mathrm{dl}$ & $3.2-4.8 \mathrm{~g} / \mathrm{dl}$ & $4.6 \mathrm{~g} / \mathrm{dl}$ & $3.2-4.8 \mathrm{~g} / \mathrm{dl}$ \\
\hline \multicolumn{2}{|l|}{ Urinalysis } & Unchanged & & Unchanged & \\
\hline \multicolumn{6}{|c|}{ Typical tests for hereditary angioedema } \\
\hline \multirow{2}{*}{$\begin{array}{l}\text { Complement component } 4 \\
\text { (C4) level }\end{array}$} & First test & $1.1 \mathrm{mg} / \mathrm{dl}$ & \multirow[t]{2}{*}{$10-40 \mathrm{mg} / \mathrm{dl}$} & $2 \mathrm{mg} / \mathrm{dl}$ & \multirow[t]{2}{*}{$10-40 \mathrm{mg} / \mathrm{dl}$} \\
\hline & Second test & $<6 \mathrm{mg} / \mathrm{dl}$ & & $6 \mathrm{mg} / \mathrm{dl}$ & \\
\hline \multirow[t]{2}{*}{ C1-inhibitor level } & First test & $91 \mathrm{mg} / \mathrm{l}$ & \multirow[t]{2}{*}{$210-390 \mathrm{mg} / \mathrm{l}$} & $67 \mathrm{mg} / \mathrm{l}$ & \multirow[t]{2}{*}{$210-390 \mathrm{mg} / \mathrm{l}$} \\
\hline & Second test & $45 \mathrm{mg} / \mathrm{dl}$ & & $44 \mathrm{mg} / \mathrm{l}$ & \\
\hline \multirow[t]{2}{*}{ C1-inhibitor activity } & First test & $14 \%$ & \multirow[t]{2}{*}{$70-130 \%$} & $24 \%$ & \multirow[t]{2}{*}{$70-130 \%$} \\
\hline & Second test & $16 \%$ & & $23 \%$ & \\
\hline
\end{tabular}

WBC - white blood cells, RBC - red blood cells, HGB - haemoglobin, HCT - haematocrit, PLT - platelets, tlgE - total lgE, slgE - specific lgE, SPT - skin prick test.

No bleeding from the digestive tract was observed after the girl turned 11, but the abdominal pains and vomiting recurred. In addition, ultrasound examinations of the abdominal cavity identified oedema of the intestinal wall and free fluid in the abdominal cavity. The symptoms and physical changes receded over a couple of days following the administration of restricted diet, analgesics, proton pump inhibitors and infusion fluids.

Two weeks before the most recent hospitalisation, at the age of 13, the patient reported vomiting, diarrhoea, and abdominal pains (VAS 10/10 points) which had sig- nificantly increased the day before arrival. On admission, although the overall condition of the girl was moderate, she was complaining of intense pains in the lower abdomen, which had continued without a break for a number of hours. Physical examination confirmed increased tension of the wall of the abdominal cavity and pain in the lower abdomen upon compression. The laboratory test results are given in Table 1 . X-ray found no irregularities in the abdominal cavity. Ultrasound identified a thickening of the intestinal wall in the ileum and caecum region and a significant amount of the free fluid in the abdomi- 
Table 2. Treatment and management in children with HAE as recommended by WAO/EAACI/HAWK $2018[1,10,15]$

\begin{tabular}{|c|c|c|}
\hline \multicolumn{3}{|l|}{ Management of podiatric HAE patients } \\
\hline Acute treatment & Short-term prophylaxis (STP) & Long-term prophylaxis (LTP) \\
\hline $\begin{array}{l}\text { 1. Plasma-derived C1-INH i.v., } 20 \mathrm{U} / \mathrm{kg} \text { : } \\
\text { - pdC1-INHBe (Berinert) } \\
\text { - pdC1-INHCi (Cinryze) }\end{array}$ & $\begin{array}{l}\text { 1. Plasma-derived C1-INH i.v., } 20 \text { U/kg: } \\
\text { - pdC1-INHBe (Berinert) } \\
\text { - pdC1-INHCi (Cinryze) }\end{array}$ & $\begin{array}{l}\text { 1. Identification and elimination of triggering } \\
\text { factors }\end{array}$ \\
\hline $\begin{array}{l}\text { 2. Recombinant human C1-INH } \\
\text { (Rhucin, Ruconest) i.v., } 50 \text { units } / \mathrm{kg}^{\mathrm{c}}\end{array}$ & $\begin{array}{l}\text { 2. Oral attenuated androgens (AAs) - can } \\
\text { be used in the absence of pdC1-INH: } \\
\text { - Danazols } 2.5 \text { to } 10 \mathrm{mg} / \mathrm{kg} / \text { day (maximum } \\
600 \mathrm{mg} \text { daily) } \\
\text { - Stanozolol and oxandrolone (used less } \\
\text { often) }\end{array}$ & $\begin{array}{l}\text { 2. Plasma-derived C1-INH pdC1-INHBe (Berinert) }{ }^{\mathrm{h}} \\
\text { i.v., } 10-20 \mathrm{U} / \mathrm{kg} / \text { dose } 1-2 \times / \text { week pdC1-INHCi } \\
\text { (Cinryze) i.v., } 1000 \cup 1-2 \times / \text { week }\end{array}$ \\
\hline 3. Ecallantide (Kalbitor) $30 \mathrm{mg} \mathrm{s.c.}{ }^{d}$ & $\begin{array}{l}\text { 3. FFP (fresh frozen plasma) i.v., } 10 \mathrm{ml} / \mathrm{kg} \\
\text { - can be used in the absence of the above } \\
\text { mentioned drugs }\end{array}$ & $\begin{array}{l}\text { 3. Antifibrinolytics - when pdC1-INH is not } \\
\text { available: } \\
\text { - Tranexamic acid (TA)i p.o. 20-50 mg/kg/day } \\
\text { split into } 2 \text { or } 3 \text { doses (maximum } 3-6 \text { g/day) } \\
\text { - Aminocaproic acid (used less often) }\end{array}$ \\
\hline $\begin{array}{l}\text { 4. FFP (fresh frozen plasma) i.v., } \\
10 \mathrm{ml} / \mathrm{kg} \text { - can be used in the } \\
\text { absence of the above mentioned } \\
\text { drugs }^{\mathrm{e}}\end{array}$ & & $\begin{array}{l}\text { 4. Oral attenuated androgens }(A A s)^{j}-\text { are } \\
\text { not considered for LTP in paediatrics prior } \\
\text { to Tanner Stage } V \text { (danazol, stanozolol, } \\
\text { oxandrolone), p.o. } 2.5 \mathrm{mg} / \mathrm{kg} \text { (max } 200 \mathrm{mg} / \text { day) }\end{array}$ \\
\hline
\end{tabular}

5. Icatibant (Firazyr), s.c., is

undergoing clinical studies

${ }^{a} p d C 1-I N H_{B e}$ registered in Europe and the USA for all age groups, for use in home therapy. ${ }^{b} p d C 1-I N H_{C i}$ registered in Europe from the age of 12 to treat acute attacks and prophylaxis (in the USA registered only for use in long-term prophylaxis). crhC1-INH registered in Europe and the USA for the treatment of acute

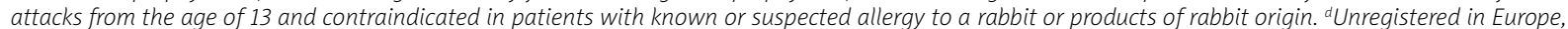
registered in the USA for the treatment of acute attacks from the age of 12; due to the risk of anaphylaxis, this drug should be administered only by a healthcare professional who has medical knowledge on the management of anaphylaxis. ${ }^{e}$ Due to the risk of transfusion transmitted diseases, solvent detergent plasma is preferred over fresh frozen plasma for safety reduction. ${ }^{f}$ Dosing for short-term prophylaxis has not been established, most experts recommend a dose of $20 \mathrm{U} / \mathrm{kg} .{ }^{9}$ Danazol is registered for STP in Europe in children from the age of 12, but not in the USA; it is worth remembering that danazol should be used for not more than 5-7 days before and 2 days after the procedure. ${ }^{h}$ dosage should be adjusted to the individual patient's response, the proposed dosage of Berinert i.v. is 10-20 U/kg 1-2x a week (maximum dose $1000 \mathrm{U} /$ day); subcutaneous delivery of pdC1-INH twice a week at 40 or $60 \mathrm{U} / \mathrm{kg}$ is considered to be effective. 'TA is registered for use in long-term prophylaxis in children in Europe and the USA, contraindicated in patients with risk factors for thrombosis and thromboembolic episodes. 'AA are registered for long-term prophylaxis in both Europe and the USA, can be used only in the absence of or contraindications to the use of pdC1INH or TA, androgen administration requires careful monitoring of safety.

nal cavity. Paracetamol and intravenous fluids were administered. The general condition improved slowly and complaints gradually resolved. Differential diagnosis was performed. The presence of repetitive paroxysmal abdominal pains, vomiting and diarrhoea, accompanied by swelling of the intestinal wall and the free fluid in the abdominal cavity, indicated HAE. The concentration and activity of C4 complement and C1-INH were clearly reduced (Table 1). Despite the negative family history, HAE type 1 was diagnosed, and after agreement with the gastroenterologist, mesalazine was discontinued.

Both patients were discharged in good general condition with a recommendation for the intravenous injection of $\mathrm{C} 1-\mathrm{INH}$ in the event of acute symptoms. The parents and patients were trained to self-administer treatment at home, and to recognise the course of the disease and its occurrence.

In both girls, HAE type 1 was diagnosed. The diagnosis was established according to Hereditary Angioedema Working Group recommendations: clinical symptoms, a C4 complement below 50\%, lowered C1-INH concentration and activity [5]. A positive family history is not essential for the diagnosis of $\operatorname{HAE}[5,6]$. Although it is a congenital condition, and the first symptoms occur before 20 years of age in almost $90 \%$ of patients [7], most of the studies on HAE concern adults. The median age of the first HAE episode ranges from seven to 13 years [8]; some patients experience attacks within the first year of life [6]. Such diversity can delay the diagnosis by one to as long as 16 years (median: eight years) [9]. This delay can be reduced by the presence of a family history of HAE $[10,11]$; however, while the time from the first symptoms to diagnosis was 6 years in the first case, in which the mother presented with similar symptoms, it took 5 years in the second case, with a negative family history.

Data on the sex distribution of HAE are varied [12, 13]. Some studies indicate that female sex as well as early onset may result in a more severe course [10]. The symptoms typically become more severe during puberty, especially in women. This was also observed in the presented patients. In the first girl, the symptoms of the disease were recurrent, namely painless swelling of the lips, hands and feet, i.e. typical first HAE symptoms in children [10]. The swelling is often painful, but without pruritus or urticaria. As in the presented cases, it develops within a few hours and usually recedes within a few hours to 
several days [10]. The differential diagnosis of HAE-associated subcutaneous tissue oedema should consider oedema of various aetiologies.

In contrast, in the second case, the only symptom was the presence of gastrointestinal complaints (recurrent abdominal pain, vomiting, diarrhoea); however, this was attributed to submucosal oedema of the gastrointestinal tract, another common symptom of HAE [10]. Paroxysmal abdominal pain can affect more than $80 \%$ of patients with HAE, nausea from $23 \%$ to $67 \%$, vomiting and flatulence from $24 \%$ to $77 \%$, and watery diarrhoea almost 9\% [10, 12, 14].

The differential diagnosis of HAE should also consider many causes of recurrent abdominal pain (also "acute abdominal pain"). A valuable diagnostic tool is ultrasound examination of the abdomen, which usually reveals free peritoneal fluid and thickening of the intestinal wall [10]. In the presented patient, each incidence of abdominal pain was associated with the presence of 21 to $70 \mathrm{~mm} / \mathrm{ml}$ free peritoneal fluid.

The most potentially dangerous symptom of HAE is submucosal oedema involving the upper respiratory tract, resulting in respiratory problems and potentially death, particularly in young children [10]. In the paediatric population, laryngeal oedema is rare $(0.9 \%)$ and is not the initial symptom of HAE. In $10 \%$ of patients with HAE, the course may be asymptomatic [12].

Although stress, trauma, hormonal changes or infections serve as typical HAE triggers, most children, like our patients, do not display any clear trigger factors [10].

HAE attacks are often preceded by the onset of prodromal symptoms, such as serpiginous erythema (42$58 \%$ ), tingling skin, local numbness and burning of skin, fatigue and irritability [10]. No such symptoms were observed in the presented patients.

Appropriate medication plays a key role in treating $\mathrm{HAE}$, both for resolving the immediate symptoms, and facilitating short and long-term prophylaxis (Table 2) [1, 10, 15].

HAE is a rare, unpredictable, potentially life-threatening and difficult-to-recognize disease. It should be considered in cases of recurrent local oedema or unexplained abdominal pain, especially with free peritoneal fluid and thickening of the intestinal wall in ultrasound examination.

\section{Conflict of interest}

The authors declare no conflict of interest.

\section{References}

1. Mauer M, Magerl M, Ansotegui I, et al. The international WAO/EAACl guideline for the management of hereditary angioedema - The 2017 revision and update. Allergy 2018; 73: 1575-96.

2. Germenis AE, Speletas M. Genetics of hereditary angioedema revisited. Clin Rev Allergy Immunol 2016; 51: 170-82.

3. Heneo MP, Kraschnewski JL, Kelbel T, et al. Diagnosis and screening of patients with hereditary angioedema in primary care. Ther Clin Risk Manag 2016; 12: 701-11.

4. Kaplan AP, Joseph K. Complement, kinins, and hereditary angioedema: mechanisms of plasma instability when $\mathrm{C} 1$ inhibitor is absent. Clin Rev Allergy Immunol 2016; 51: 207-15.

5. Cicardi M, Aberer W, Banerji A, et al. Classification, diagnosis, and approach to treatment for angioedema: consensus report from the Hereditary Angioedema International Working Group. Allergy 2014; 69: 602-16.

6. Craig TJ, Schneider LC, MacGinnitie AJ. Plasma-derived C1INH for managing hereditary angioedema in pediatric patients: a systematic review. Pediatr Allergy Immunol 2015; 26: 537-44.

7. Sabharwal G, Craig T. Pediatric hereditary angioedema: an update. F1000Research 2017; 6: 1205.

8. Nanda MK, Elenburg S, Berstein JA, et al. Clinical features of pediatric hereditary angioedema. J Allergy Clin Immunol 2015; 3: 392-5.

9. Mehmet YO, Ozlem K, Nazan B, et al. A hereditary angioedema screening in two villages, based on an index case, and identification of a novel mutation, "1033G > T", at the SERPING1 gene. Adv Dermatol Allergol 2019; 36: 403-11.

10. Farkas H, Martinez-Saguer I, Bork K, et al. International consensus on the diagnosis and management of pediatric patients with hereditary angioedema with $\mathrm{C} 1$ inhibitor deficiency. Allergy 2017; 72: 300-13.

11. Aabom A, Andersen KE, Fagerberg C, et al. Clinical characteristics and real-life diagnostic approaches in all Danish children with hereditary angioedema. Orphanet J Rare Dis 2017; 12: 55.

12. Fragnan NTML, Tolentino ALN, Borba GB, et al. Hereditary angioedema with $\mathrm{C} 1$ inhibitor (C1-INH) deficit: the strength of recognition (51 cases). Braz J Med Biol Res 2018; 51: e7813.

13. Bennett $G$, Craig T. Hereditary angioedema with a focus on the child. Allergy Asthma Proc 2015; 36: 70-3.

14. Rubinstein E, Stolz LE, Sheffer AL, et al. Abdominal attacks and treatment in hereditary angioedema with C1-inhibitor deficiency. BMC Gastroenterology 2014; 14: 71.

15. Li HH, Mycroft S, Christiansen S, et al. Subcutaneous C1 - esterase inhibitor to prevent hereditary angioedema attacks: safety findings from the COMPACT trial. Allergy Asthma Proc 2018; 39: 365-70. 